Article

\title{
Effect of Soil Tillage and Crop Sequence on Grain Yield and Quality of Durum Wheat in Mediterranean Areas
}

\author{
Giancarlo Pagnani ${ }^{1}$, Angelica Galieni ${ }^{2}$, Sara D'Egidio ${ }^{1}$, Giovanna Visioli ${ }^{3} \mathbb{D}$, Fabio Stagnari ${ }^{1, *}$ \\ and Michele Pisante ${ }^{1}$ \\ 1 Faculty of Bioscience and Technologies for Food, Agriculture and Environment, University of Teramo, \\ 64100 Teramo (TE), Italy \\ 2 Council for Agricultural Research and Economics, Vegetable and Ornamental Crops Research Center, \\ 63077 Monsampolo del Tronto (AP), Italy \\ 3 Department of Chemistry, Life Sciences and Environmental Sustainability University of Parma, \\ Parco Area delle Scienze 11/A, 43124 Parma, Italy \\ * Correspondence: fstagnari@unite.it
}

Received: 8 August 2019; Accepted: 27 August 2019; Published: 28 August 2019

\begin{abstract}
Conservation agriculture (CA) can be very strategic in degradation prone soils of Mediterranean environments to recover soil fertility and consequently improve crop productivity as well as the quality traits of the most widespread crop, durum wheat, with reference to protein accumulation and composition. The results shown by two years of data in a medium long-term experiment (7-year experiment; split-plot design) that combined two tillage practices (conventional tillage (CT) and zero tillage (ZT)) with two crop sequences (wheat monocropping (WW) and wheat-faba bean (WF)) are presented. The combination ZT + WF (CA approach) induced the highest grain yields (617 and $370 \mathrm{~g} \mathrm{~m}^{-2}$ in 2016 and 2017, respectively), principally due to an increased number of ears $\mathrm{m}^{-2}$; on the other hand, the lowest grain yield was recorded under CT + WW (550 and $280 \mathrm{~g} \mathrm{~m}^{-2}$ in 2016 and 2017, respectively). CA also demonstrated significant influences on grain quality because the inclusion of faba bean in the rotation favored higher N-remobilization to the grains (79.5\% and $77.7 \%$ in 2017). Under ZT and WF, all gluten fractions (gliadins (Glia), high molecular-weight glutenins (GS), and low molecular-weight GS) as well as the GS/Glia ratio increased. In durum wheat-based farming systems in Mediterranean areas, the adoption of CA seems to be an optimal choice to combine high quality yields with improved soil fertility.
\end{abstract}

Keywords: no-tillage; conservation agriculture; durum wheat; gluten fractions; SDS-PAGE analysis

\section{Introduction}

Durum wheat is the main cereal crop grown within Mediterranean regions, although the erratic rainfall distribution and the extremely fluctuating temperatures during grain filling stages determine the instability of yields. In these areas, wheat is usually grown in monocropping or short rotations, in conventionally managed soils (ploughing and harrowing) characterized by severe water loss, erosion, organic matter depletion, and $\mathrm{CO}_{2}$ release. Both the reduced soil fertility and effects of climatic change strongly affect durum wheat yields and quality traits [1]. To counteract such criticality, conservation agriculture (CA) practices-based on (i) minimum or no soil disturbance; (ii) permanent residue cover; and (iii) planned crop rotations or associations [2] should be applied; these aim to promote water conservation, biological processes, and organic matter accumulation due to reduced soil erosion and $\mathrm{CO}_{2}$ emissions. Although the environmental sustainability of $\mathrm{CA}$ and its positive effects on crop yield 
in rainfed systems have been documented [2-6], data on CA impact on crop quality traits as well as on yield-quality relationships are missing.

In durum wheat, the protein content as well as the protein profiles play a key role in the technological quality. Gluten, which represents $80 \%$ of kernel proteins, can be classified into prolamins, namely gliadins (Glia) that are alcohol soluble proteins, and glutenins (GS) that are soluble in diluted acid or alkali or alcohol-water mixtures, while the rest $20 \%$ is composed by non-prolamins including albumins, globulins, and metabolic enzymes which are water and salt soluble [7]. Glia and GS exert the highest influence on the strength and elastic proprieties of the dough. Glia can be classified into S-rich prolamins (i.e., $\alpha-\beta$ - $\gamma$-gliadins, molecular weight $36-44 \mathrm{kDa}$ ), and S-poor prolamins (i.e., $\omega$-gliadins, molecular weight 44-78 kDa). GS consist of different sub-units, high molecular weight GS (HMW-GS, 80-140 kDa), and low molecular weight GS (LMW-GS, 31-51 kDa), which form large aggregates joined by disulfide bonds. The GS/Glia ratio determines the functional proprieties of the gluten responsible for dough strength [8], and greater dough strength is observed when there are higher proportions of the HMW-GS than that of the LMW-GS polymer [9]. Several allelic variants of $x$ and $y$ genes coding for HMW-GS have been associated with flour technological quality [10] as well as the B-group LMW-GS, coded at Glu-3 loci at chromosome 1 (Glu-A3, Glu-B3, and Glu-B2) [11].

Aside from genetics, the main role in determining the amount and specificity of durum wheat proteins is caused environmentally and agronomically, especially in terms of the up or downregulation of specific Glia, HMW-GS, and LMW-GS sub-units that are related to flour quality [9,12-14]. In particular, temperatures, precipitation, and nitrogen $(\mathrm{N})$ availability during grain filling are key factors for seed protein accumulation $[15,16]$. The synthesis and accumulation of gluten proteins is increased significantly by $\mathrm{N}$ availability, although the effect is principally driven by the efficient synchrony between soil $\mathrm{N}$ and plant $\mathrm{N}$ requirements $[14,17,18]$. Besides, fertilization strategies $[18]$ as well as soil management, cover crops, and crop rotation are fundamental variables that affect physiological traits, and consequently, the quality (protein profile) and yields [19]. Crop rotation and residues influence carbon and $\mathrm{N}$ dynamics in soil [20], especially in low organic matter and $\mathrm{N}$ environments (i.e., Mediterranean areas); crop residues on soil surface are, indeed, not only mere soil protectors from erosion, but affect nutrient and water availability that in turn increase and stabilize yields [21-25].

However, the adoption of CA requires a transition phase (on average 7-8 years), often characterized by higher annual weed and disease pressures, slow rebuilding aggregates in soil, and lower and variable yields, so involve adaptations at the individual farm-level until the rehabilitation of soil-related functions [26].

Studies regarding the effect of CA practices on protein accumulation in durum wheat kernel, especially on storage proteins and their composition, are lacking. Durum wheat quality has been principally investigated in association with different tillage [27], while the effect of the interaction of the CA key practices in a holistic view on crop physiology, yield, and technological quality performances are still missing. To this end, we propose a comprehensive approach based on the combination of two tillage practices (conventional tillage and zero tillage) with two crop sequences (wheat monocropping and wheat-faba bean) including the CA approach in a medium-long term (7-years) experiment to investigate durum wheat responses. A short not-irrigated rotation, which is typical of the experimental area (Mediterranean area), was adopted (although it does not fully meet the requirements of $C A$ ). We raised the hypothesis that through the conservation approach (zero tillage and residue retention, crop rotation), already at the end of the transition phase, the soil quality amelioration reflected into improved crop performances in terms of:

(i) growth, yield and yield components;

(ii) protein accumulation and profile total grain protein, Glia, LMW-GS, and HMW-GS, and the characterization of the single sub-units of gluten proteins; and

(iii) crop physiological status, efficiencies of biomass and nitrogen remobilization to kernels, reflectance-based vegetation indices. 


\section{Materials and Methods}

\subsection{Site Description}

The results reported in this study were obtained during the 2015-2016 and 2016-2017 cropping seasons (referred below as 2016 and 2017, respectively) within a medium-long term experiment started in 2010-2011 in Teramo (Mosciano Sant'Angelo, Italy, 42 $42^{\prime}$ N, 13 $52^{\prime}$ E, $101 \mathrm{~m}$ above sea level). The principal soil characteristics, recorded at the beginning of the experiment, were as follows: $23 \%$ sand, $45 \%$ silt, and $32 \%$ clay, $\mathrm{pH} 8.0,1.36 \%$ organic carbon, $19.0 \%$ total $\mathrm{CaCO}_{3}, 10.6 \%$ active $\mathrm{CaCO}_{3}$, and $32.1 \mathrm{meq} 100 \mathrm{~g}^{-1}$ cation-exchange capacity. The area has a typical Mediterranean climate with $732 \mathrm{~mm}$ of annual mean rainfall (58-year period) mainly concentrated between October and April; the mean of maximum temperatures ranges from $11^{\circ} \mathrm{C}$ to $29^{\circ} \mathrm{C}$ while the mean of minimum temperatures ranges from $2{ }^{\circ} \mathrm{C}$ to $17{ }^{\circ} \mathrm{C}$. During crop cycles, meteorological data were recorded with a meteorological station situated at about $1 \mathrm{~km}$ from the experimental field; trends of average minimum and maximum monthly air temperatures and total rainfall are reported in Figure 1.
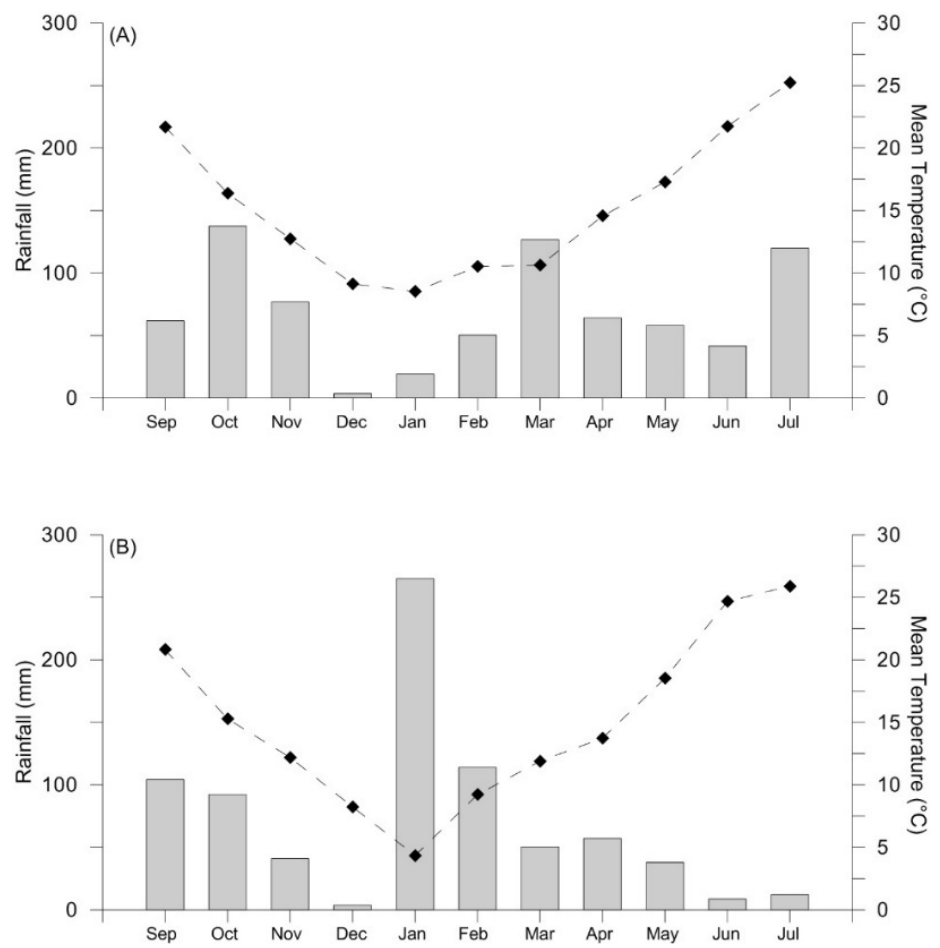

Figure 1. Monthly rainfall (bars) and monthly average temperatures (dots) as registered during the whole durum wheat crop cycle in the two different growing seasons, 2015-2016 (A) and 2016-2017 (B) at the experimental area.

\subsection{Experimental Design and Agronomic Practices}

The medium-long term experiment aimed to evaluate different management systems for durum wheat (scenarios) under a semi-arid environment by combining two soil tillage practices (ST, main treatment, main plots) with two crop sequences (secondary treatments) in a split-plot design with three replications. The soil tillage practices consisted of conventional tillage (CT) and zero tillage (ZT). CT and ZT were established in a 15,000 $\mathrm{m}^{2}$ experimental field, properly spaced (i.e., field margins, edges, and traffic infrastructure) to avoid any overlays during tillage operations and were imposed starting from the beginning of the medium-long term experiment (2010-2011). It follows that the ZT treatment respected a six/seven-year period of conversion (2010-2016/2017) necessary to ensure reliable long-term production goals [28]. CT included complete soil inversion (moldboard ploughing) to a 35-cm depth during the summer, followed by secondary tillage in the autumn. ZT involved no soil disturbance, 
previous-crop residue retention, and a glyphosate (Roundup Power 2.0, Monsanto Agricoltura Italia S.p.A., Milano (MI), Italy) application at the rate of $2 \mathrm{~L} \mathrm{ha}^{-1}$, two weeks before sowing.

Within each soil tillage practice, two different crop sequences (CS, secondary treatment, sub-plots) were established: (i) durum wheat (Triticum turgidum L. subsp. durum (Desf.) Husn.) monocropping (WW); and (ii) a durum wheat-faba bean (Vicia faba L. var. minor) rotation (WF), rising to a total of 18 sub-plots. Each sub-plot consisted of an area of $1200 \mathrm{~m}^{2}$ and was obtained by splitting the main plots into three areas of equal size that, according to the length of the crop cycles, were able to host both monocropping and rotation treatments (each crop present every year). Within the sub-plots, transects were set up in order to obtain two experimental units of $20 \mathrm{~m}^{2}(2.5 \mathrm{~m} \times 8.0 \mathrm{~m})$ for sampling and data collection. In order to avoid edge-effects, the experimental units were delimited in the central area of each sub-plot. Edges between treatments were managed, leaving them free from crops and weeds using a brushcutter.

Treatments under comparison were obtained from the factorial combination of tillage and crop sequence, as follows: (i) conventional tillage and wheat monocropping $(\mathrm{CT}+\mathrm{WW})$; (ii) conventional tillage and wheat-faba bean rotation $(\mathrm{CT}+\mathrm{WF})$; (iii) zero tillage and wheat monocropping $(\mathrm{ZT}+\mathrm{WW})$; and (iv) zero tillage and wheat-faba bean rotation ( $\mathrm{ZT}+\mathrm{WF}$ ). In the ZT + WF treatment, despite the short rotation, which was chosen to conveniently reflect the typical agronomic management of the area, all three principles of CA were respected.

The durum wheat and faba bean cultivars were "Saragolla" and "Protabath", respectively. Both crops were sown on 7 December and 23 November in 2016 and 2017, respectively, at a rate of 350 and 50 viable seeds $\mathrm{m}^{-2}$ for durum wheat and faba bean, respectively. A direct seeder (Gaspardo Direttissima, Gruppo Maschio Gaspardo S.p.A., Campodarsego, PD, Italy) was used in the ZT treatments while a mechanical seeder (S-SC MARIA 250, Gruppo Maschio Gaspardo S.p.A., Campodarsego, PD, Italy) was used in the CT treatments. In durum wheat, $\mathrm{N}$ was applied at the whole rate of $150 \mathrm{~kg} \mathrm{~N} \mathrm{ha}^{-1}$, split into half on 22 March 2016 and 28 March 2017 (beginning of stem elongation) as ammonium nitrate and half on 18 April 2016 and 20 April 2017 (emergence of head complete) as urea; no fertilization treatments were applied to the faba bean. In both years, the fungicide Sphere (Trifloxystrobin and Ciproconazolo, Bayer Crop Science Italia, MI, Italy) was applied at the dose of $1 \mathrm{~L} \mathrm{ha}^{-1}$, at the beginning of anthesis; herbicide treatments were not performed.

Immediately after sowing, the number of crop residues (thickness and weight) was measured for the ZT + WW and ZT + WF treatments on a sampling square of $0.25 \mathrm{~m}^{2}$ for each experimental unit. Crop residues were also characterized for their $\mathrm{N}$ concentration (Kjeldahl procedure) and for their cellulose, hemicellulose, and lignin contents [29].

\subsection{Plant Sampling and Growth Analysis}

Phenological stages were constantly monitored on 10 randomly tagged plants per experimental unit and were scored following the Zadoks Decimal Code [30].

Starting from anthesis (29 April and 27 April for 2016 and 2017, respectively), 10 whole main wheat shoots within each experimental unit were randomly collected until the final harvest (23 June and 19 June for 2016 and 2017, respectively) at the following phenological stages: DC71, DC73, DC83, DC87, and DC91 in 2016 and DC71, DC77, DC85, DC87, and DC91 in 2017, which corresponded to 0, $165,256,404,564$, and 660 growing degree days (GDD, ${ }^{\circ} \mathrm{C}$ ) in 2016 and to $0,168,310,443,523$, and 630 GDD in 2017. Thermal time after anthesis (GDD) corresponded to the cumulative daily average air temperature exceeding $0{ }^{\circ} \mathrm{C}$.

Sampled plants were separated into leaves, stems, and ears. Dry weight (DW) was measured after oven drying at $80{ }^{\circ} \mathrm{C}$ until reaching a constant weight.

According to Arduini et al. [31], the amount of vegetative DW remobilized into kernels during grain filling (DW remobilization efficiency, DWRemE, \%) was calculated as the difference between the DW of the aerial plant part at heading and at physiological maturity. 
At physiological maturity, one square meter of wheat plants was randomly harvested to measure the yield components (ears number $\mathrm{m}^{-2}$ and length $(\mathrm{cm})$ ) and yield $\left(\mathrm{g} \mathrm{m}^{-2}\right)$ after hand threshing.

\subsection{N Determination in Plant Tissues}

In both 2016 and 2017, the $\mathrm{N}$ concentration in vegetative (leaves, stems) and reproductive (ears) organs was determined at the DC71 and DC91 durum wheat phenological phases, followed by the Kjeldahl method. $\mathrm{N}$ content was then calculated by multiplying the $\mathrm{N}$ concentration by DWs. At harvest, the grain protein content (GPC, \%) was also calculated as the grain $\mathrm{N}$ concentration multiplied by 5.7 [32].

The $\mathrm{N}$ remobilization efficiency (NRemE, \%) was calculated as DWRemE, according to Arduini et al. [31].

\subsection{Analysis of Gluten Proteins}

\subsubsection{Extraction and Quantification}

Grain sub-samples collected from each experimental unit were milled with Knifetec TM 1095 (Foss, Hillerød, Denmark) to obtain a fine powder, and $30 \mathrm{mg}$ of wholemeal flour was used to evaluate the Glia, HMW-GS, and LMW-GS fractions by applying some modifications to the sequential procedure described in Singh et al. [33]. Flour was suspended in $1.5 \mathrm{~mL}$ of $50 \%(v / v)$ propan-2-ol for $20 \mathrm{~min}$ with continuous mixing at $65^{\circ} \mathrm{C}$; followed by centrifugation for $5 \mathrm{~min}$ at $10,000 \mathrm{rpm}$. The supernatant contained the extracted Glia component, which was collected and evaporated to dryness in a speed Vac concentrator (Svant Instruments, Farmingdale, NY, USA). A pellet containing the GS fraction, after washing twice with 50\% (v/v) propan-2-ol, was suspended again within a solution of $55 \%(v / v)$ propan-2-ol, $0.08 \mathrm{M}$ tris(hydroxymethyl) aminomethane hydrochloric acid $\mathrm{pH} 8.3$, and $1 \%(w / v)$ dithiothreitol as a reducing agent and incubated for $30 \mathrm{~min}$ at $60^{\circ} \mathrm{C}$ with continuous mixing. After centrifugation for $5 \mathrm{~min}$ at 14,000 rpm, the supernatant containing both the HMW-GS and LMW-GS fractions was transferred into a new tube. Acetone was then added to reach a final concentration of $40 \%$ $(v / v)$ to precipitate HMW-GS. After centrifugation for $5 \mathrm{~min}$ at $13,000 \mathrm{rpm}$, the pellet was evaporated to dryness while the remaining supernatant containing the LMW-GS fraction was recovered into a new tube and precipitated by adding acetone to reach a final concentration of $80 \%(v / v)$. After centrifugation, the supernatant was discarded, and the pellet was air dried. Both protein fractions were quantified with the Bradford assay (Biorad Hercules, CA, USA) after dissolving pellets in (50:50 v/v) acetonitrile and $\mathrm{H}_{2} \mathrm{O}$ with $0.1 \%(v / v)$ trifluoroacetic acid. Three technical replicates were performed for each sample.

\subsubsection{Sub-Units Separation by SDS-PAGE and Densitometric Analyses}

In order to deeply investigate the effects of the experimental treatments in terms of up or downregulation of single sub-units of the LMW-GS, HMW-GS, and Glia, Sodium Dodecyl Sulphate-PolyAcrylamide Gel Electrophoresis (SDS-PAGE)was performed on a Mini-PROTEAN Tetra Cell (Bio-Rad, CA, USA) on $8 \%$ and $12 \%$ acrylamide gel for the HMW-GS and LMW-GS and Glia, respectively, in 2017. Dried HMW-GS and LMW-GS and Glia (2.5 $\mu \mathrm{g}$ each) were suspended in $20 \mu \mathrm{L}$ of loading buffer containing $2 \%(w / v)$ SDS, $0.02 \%(w / v)$ bromophenol blue, $0.1 \% \beta$-mercaptoethanol, $0.05 \mathrm{M}$ Tris- $\mathrm{HCl} \mathrm{pH} \mathrm{6.8,} \mathrm{and} 10 \%(v / v)$ glycerol, and boiled at $95{ }^{\circ} \mathrm{C}$ for $5 \mathrm{~min}$ before loading onto the gel. A ColorBurst ${ }^{\mathrm{TM}}$ Marker Electrophoresis High Range (Mw 30,000-220,000) was used to detect HMW-GS and a Molecular-Weight Marker ${ }^{\circledR}$ (Mw 14,000-66,000; Sigma Aldrich, St. Louis, MO, USA) to detect LMW-GS. After electrophoretic separation at $40 \mathrm{~mA}$, the gels were stained with brilliant blue G-colloidal solution (Sigma Aldrich, St. Louis, MO, USA) fixed in $7 \%(v / v)$ acetic acid and $40 \%(v / v)$ methanol, and de-stained in 25\% (v/v) methanol. Each protein sample (Glia, HMW-GS, and LMW-GS) was analyzed in three technical replicates. IMAGE lab 4.5.1 (Bio-Rad) software was used to identify protein molecular weights (MW) and for relative quantification of the LWM-GS and HMW-GS single protein sub-units on each gel. 


\subsection{Physiological Traits}

At the DC85 developmental stage, canopy reflectance was measured using a HandHeld 2 Pro Portable FieldSpec Spectroradiometer (ADS Inc., Boulder, CO, USA). The normalized difference vegetation index (NDVI), green normalized difference vegetation index (GNDVI), water index (WI) and optimized soil adjusted vegetation index (OSAVI) were then calculated as follows [34-37]:

$$
\begin{gathered}
N D V I_{670}=(\rho 800-\rho 670) /(\rho 800+\rho 670) \\
\text { GNDVI }=(\rho 750-\rho 550) /(\rho 750+\rho 550) \\
W I=\rho 900 / \rho 970 \\
\text { OSAVI }=(1+0.16)(\rho 800-\rho 670) /(\rho 800-\rho 670+0.16)
\end{gathered}
$$

where $p$ represents the reflectance measured at the specific wavelength.

The estimation of the chlorophyll content was obtained with the SPAD 502 plus portable chlorophyll meter (Konica Minolta, Inc., Tokyo, Japan). In order to avoid the natural yellowing of the older leaves, measurements were taken on the mid-section of the flag leaf, when present or otherwise, on the greenest leaf, for a total of 10 measurements for each experimental unit.

\subsection{Statistical Analysis}

Analysis of variance (ANOVA) was performed with the free Excel plugin DSAASTAT ${ }^{\circledR}$ VBA macro, version 1.1 (Pisa, Italy) [38], considering a multi-year split-plot design in order to test (F-test) the effects of growing season (year), ST, and CS as well as their interactions on the selected variables. Year was considered as a random factor. Densitometric data related to Glia, HMW-GS, and LMW-GS sub-units recorded in 2017 were analyzed using a two-way ANOVA considering a split-plot design.

When ANOVA detected significant differences, the means were separated by applying the Tukey's honestly significant difference (HSD) test (data in Tables). In the figures, the standard errors of the means are reported. Normality and homoschedasticity assumptions were tested with the Shapiro-Wilk and Bartlett tests, respectively (R software, Vienna, Austria) [39].

\section{Results}

\subsection{Meteorological Data, Residue Retention, and Composition}

Erratic amounts and distribution of rainfall characterized the experiments (Figure 1). In 2017, between anthesis and grain filling, the cumulative rainfall was 50\% less than 2016 (290.2 $\mathrm{mm}$ vs. $153.8 \mathrm{~mm}$ in 2016 and 2017, respectively) while during the vegetative phase (sowing-anthesis period), values were higher and mainly concentrated in January (Figure 1). Generally, the monthly average temperatures were similar between the two years (15.3 and $15.0^{\circ} \mathrm{C}$ for 2016 and 2017, respectively).

ZT favored the accumulation of residue mulching, which showed a remarkable thickness $(0.93 \mathrm{~cm}$ on average) and weight ( $2.00 \mathrm{tha}^{-1}$ on average) (Table 1). Residues obtained under WW showed a higher thickness and weight than WF (1.40 vs. $0.46 \mathrm{~cm}$ and $\left.3.06 \mathrm{vs.} 0.95 \mathrm{t} \mathrm{ha}^{-1}\right)$ and were characterized by a greater percentage of hemicellulos, cellulose, and lignin, but with lower $\mathrm{N}$ content (Table 1).

Table 1. Thickness $(\mathrm{cm})$, amount $\left(\mathrm{t} \mathrm{ha}^{-1}\right)$, nitrogen $(\mathrm{N}, \%)$, hemicellulose $(\%)$, cellulose $(\%)$, and lignin (\%) contents of durum wheat and faba bean residues under zero tillage (ZT) treatments (durum wheat residues: $\mathrm{ZT}+$ wheat monocropping $(\mathrm{ZT}+\mathrm{WW})$; faba bean residues: $\mathrm{ZT}+$ wheat-faba bean rotation $(\mathrm{ZT}+\mathrm{WF})$ ). Means \pm standard errors (over growing seasons) are reported.

\begin{tabular}{ccccccc}
\hline Crop Sequence & Thickness (cm) & Amount (t ha-1) & N (\%) & Hemicellulose (\%) & Cellulose (\%) & Lignin (\%) \\
\hline ZT + WW & $1.40 \pm 0.12$ & $3.06 \pm 0.14$ & $0.3 \pm 0.02$ & $24.4 \pm 0.28$ & $33.4 \pm 0.11$ & $15.2 \pm 0.01$ \\
ZT + WF & $0.46 \pm 0.08$ & $0.95 \pm 0.07$ & $1.68 \pm 0.03$ & $15.5 \pm 0.34$ & $23.4 \pm 0.27$ & $4.0 \pm 0.03$ \\
\hline
\end{tabular}




\subsection{Dry Mass Dynamics and Partitioning}

The dynamics of the DW accumulation of the leaves, stems, and ears starting from 165 and 168 GDD after anthesis (2016 and 2017, respectively) are reported in Figure 2. Averaging over treatments, slightly higher dry aerial biomass values were obtained in 2016 (leaves: 0.53 vs. 0.38 g plant $^{-1}$; stem: 1.79 vs. 1.68 g plant $^{-1}$; ear: 2.20 vs. 2.17 g plant $^{-1}$ in 2016 and 2017, respectively) with ZT often showing higher values than CT (at harvesting, ZT vs. CT: leaves $+32 \%$, stems $+15 \%$, ears $+11 \%$ ) (Figure 2 ).
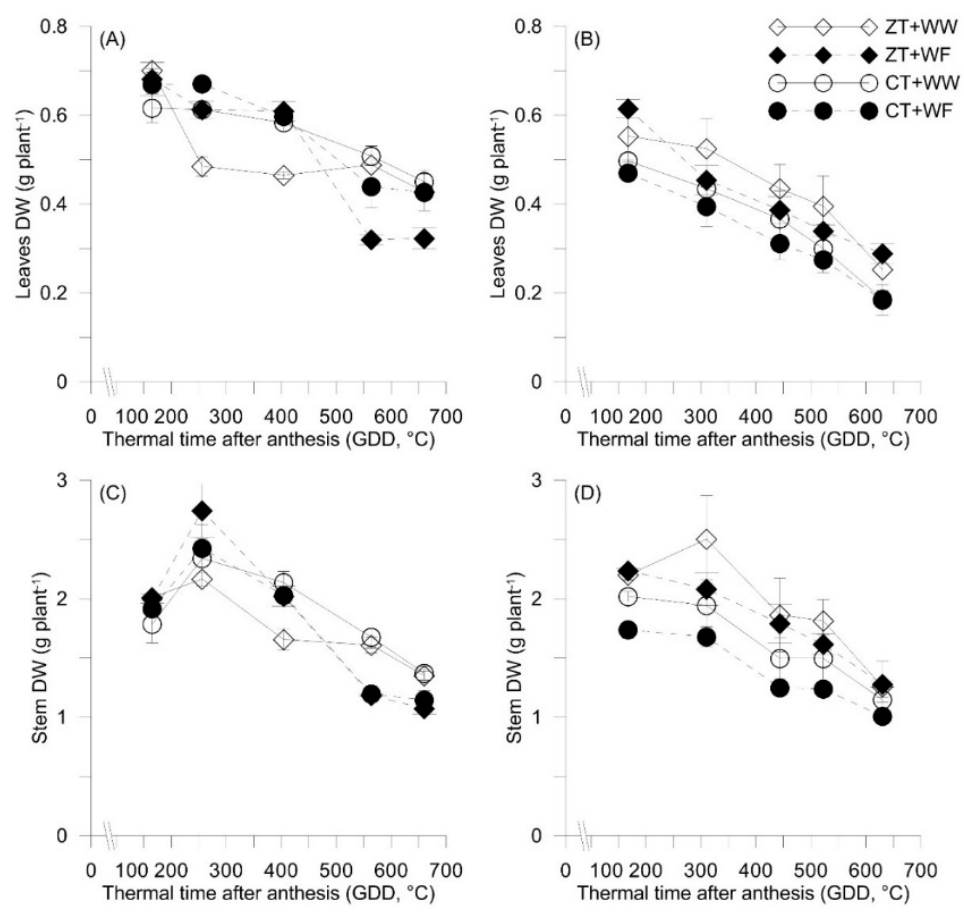

$3-$ (D)
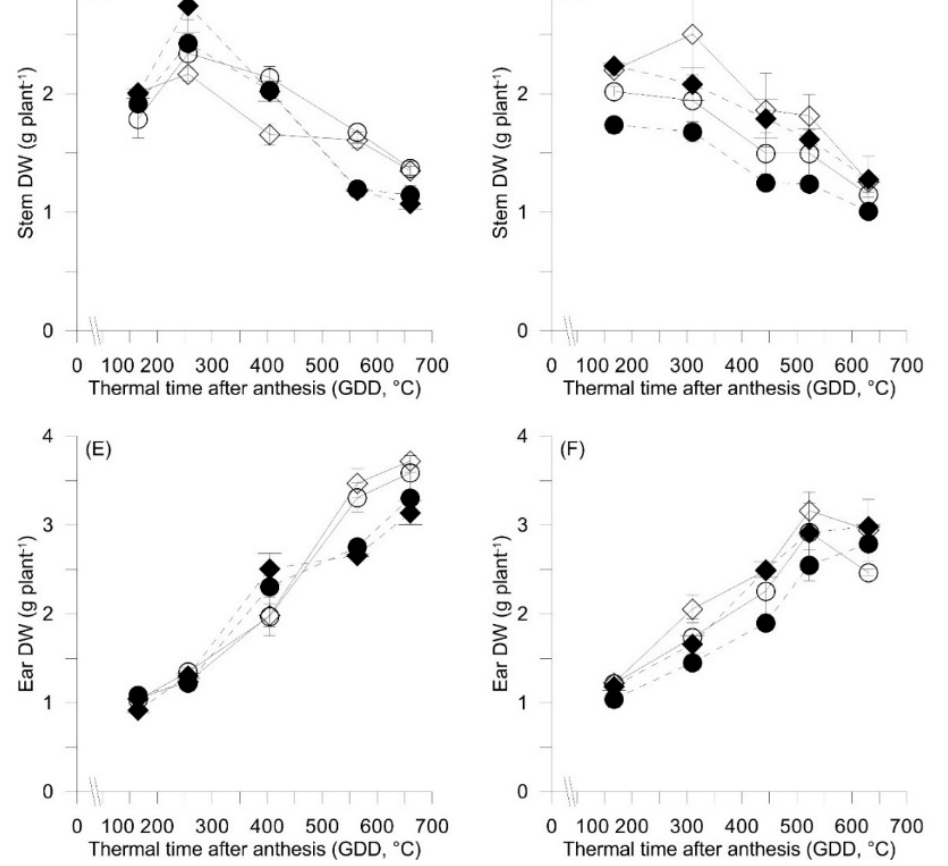

Figure 2. Dynamic of dry weight (DW, g plant $\left.{ }^{-1}\right)$ of leaves, steam and ear against thermal time after anthesis $\left({ }^{\circ} \mathrm{C}\right.$ ) of durum wheat in 2016 (A, C and E, respectively) and 2017 (B, D and F, respectively) affected by soil tillage practice and crop sequence $(\bigcirc \mathrm{CT}+\mathrm{WW} ; \bullet \mathrm{CT}+\mathrm{WF} ; \diamond \mathrm{ZT}+\mathrm{WW} ; \mathrm{ZT}+\mathrm{WF})$. Treatments: CT, conventional tillage; ZT, zero tillage; WW, durum wheat monocropping; WF, durum wheat-faba bean rotation. Data are averages \pm standard errors of $n=3$ independent replicates.

During grain filling, 36.2\% and 45.9\% of the vegetative DW were remobilized in 2016 and 2017 (averaging over ST and CS), respectively (Table 2). Although differences between ST treatments were not significant (Table 3), ZT induced higher DWRemE than CT (43.7\% vs $38.4 \%)$; furthermore, WF induced higher DWRemE than WW. Consequently, the highest value was registered for the ZT + WF combination $(47.9 \%)$ while the lowest was obtained for CT + WW (23.3\%) (Table 2). 
Table 2. Dry weight (DW) remobilization efficiency (DWRemE, \% of vegetative DW) and nitrogen (N) remobilization efficiency (NRemE, \% of vegetative N) in the 2016 and 2017 cropping seasons. Means followed by different letters (upper case letters: main effects; lower case letters: effects of interaction) significantly differ according to Tukey's HSD test $(p<0.05)$. Treatments: CT, conventional tillage; ZT, zero tillage; WW, durum wheat monocropping; WF, durum wheat-faba bean rotation.

\begin{tabular}{|c|c|c|c|c|c|c|c|}
\hline \multirow{2}{*}{ Year } & \multirow{2}{*}{ Treatments } & \multicolumn{3}{|c|}{ DWRemE (\%) } & \multicolumn{3}{|c|}{ NRemE (\%) } \\
\hline & & $\mathrm{ZT}$ & $\mathrm{CT}$ & CS mean & $\mathrm{ZT}$ & CT & CS mean \\
\hline \multirow[t]{3}{*}{2016} & WW & 34.4 & 23.3 & 28.8 & 74.2 & 73.6 & 73.9 \\
\hline & WF & 47.9 & 39.3 & 43.6 & 82.4 & 76.6 & 79.5 \\
\hline & ST mean & 41.2 & 31.3 & & $78.3 \mathrm{~A}$ & $75.1 \mathrm{~B}$ & \\
\hline \multirow[t]{3}{*}{2017} & WW & 45.5 & 45.1 & 45.3 & 72.8 & 76.6 & 74.7 \\
\hline & WF & 47.1 & 45.9 & 46.5 & 76.1 & 78.8 & 77.4 \\
\hline & ST mean & 46.3 & 45.5 & & $74.4 \mathrm{~B}$ & $77.7 \mathrm{~A}$ & \\
\hline \multirow[t]{3}{*}{ 2016-2017 } & WW & 40.0 & 34.2 & 37.1 & 73.5 & 75.1 & 74.3 \\
\hline & WF & 47.5 & 45.6 & 47.0 & 79.2 & 77.7 & 78.4 \\
\hline & ST mean & 43.7 & 38.4 & & 76.3 & 76.4 & \\
\hline
\end{tabular}

Effects: ST, soil tillage; CS, crop sequence. Degrees of freedom: Year, 1; ST, 1; Year $\times$ ST, 1; CS, 1; Year $\times$ CS, 1; $\mathrm{ST} \times \mathrm{CS}, 1$; Year $\times \mathrm{ST} \times \mathrm{CS}, 1$; Residual, 8 .

Table 3. Summary of $p$-values from the analyses of variance for dry weight remobilization efficiency (DWRemE, \% of vegetative DW), nitrogen remobilization efficiency (NRemE, \% of vegetative N), yield $\left(\mathrm{g} \mathrm{m}^{-2}\right)$, number of ears per square meter (ears, num ${ }^{-2}$ ), ear length $(\mathrm{cm}), \mathrm{N}$ concentrations ([N]) in leaves $\left(\mathrm{g} \mathrm{kg}^{-1}\right),[\mathrm{N}]$ in stems $\left(\mathrm{g} \mathrm{kg}^{-1}\right)$, and [N] in ears $\left(\mathrm{g} \mathrm{kg}^{-1}\right), \mathrm{N}$ content in leaves $\left(\mathrm{g} \mathrm{m}^{-2}\right), \mathrm{N}$ content in stems $\left(\mathrm{g} \mathrm{m}^{-2}\right)$, $\mathrm{N}$ content in ears $\left(\mathrm{g} \mathrm{m}^{-2}\right)$, grain protein content (GPC, \%), gliadins (Glia, $\left.\mathrm{mg} \mathrm{g}^{-1}\right)$, high molecular weight glutenins (HMW-GS, $\mathrm{mg} \mathrm{g}^{-1}$ ), low molecular weight glutenins (LMW-GS, mg $\mathrm{g}^{-1}$ ), normalized vegetation index (NDVI), green normalized difference vegetation index (GNDVI), soil-adjusted vegetation index optimized (OSAVI), water index (WI) and SPAD. Effects: ST, soil tillage; CS, crop sequence. Degrees of freedom: Year, 1; ST, 1; Year $\times$ ST, 1; CS, 1; Year $\times$ CS, 1; ST $\times$ CS, 1; Year $\times$ ST $\times$ CS, 1 ; Residual, 8 .

\begin{tabular}{|c|c|c|c|c|c|c|}
\hline & ST & Year $\times$ ST & CS & Year $\times$ CS & $\mathrm{ST} \times \mathrm{CS}$ & Year $\times \mathrm{ST} \times \mathrm{CS}$ \\
\hline DWRemE & 0.446 & 0.133 & 0.449 & 0.057 & 0.669 & 0.800 \\
\hline NRemE & 0.994 & 0.013 & 0.210 & 0.354 & 0.370 & 0.495 \\
\hline Yield $\left(\mathrm{g} \mathrm{m}^{-2}\right)$ & 0.204 & 0.146 & 0.002 & 0.986 & 0.192 & 0.420 \\
\hline Ears (num m ${ }^{-2}$ ) & 0.038 & 0.813 & 0.515 & 0.095 & 0.171 & 0.117 \\
\hline Ear length (cm) & 0.734 & 0.001 & 0.129 & 0.125 & 0.706 & 0.005 \\
\hline \multicolumn{7}{|l|}{ [N] Leaves } \\
\hline DC71 ${ }^{\mathrm{a}}$ & 0.880 & 0.033 & 0.449 & 0.012 & 0.428 & 0.165 \\
\hline DC $91^{\mathrm{a}}$ & 0.716 & 0.081 & 0.749 & 0.057 & 0.119 & 0.588 \\
\hline \multicolumn{7}{|l|}{$[\mathrm{N}]$ Stems } \\
\hline DC71 & 0.846 & 0.150 & 0.020 & 0.915 & 0.178 & 0.569 \\
\hline DC91 & 0.777 & 0.137 & 0.455 & 0.521 & 0.406 & 0.310 \\
\hline \multicolumn{7}{|l|}{$[\mathrm{N}]$ Ears } \\
\hline DC71 & 0.133 & 0.899 & 0.222 & 0.248 & 0.193 & 0.481 \\
\hline DC91 & 0.620 & 0.037 & 0.664 & 0.001 & 0.249 & 0.626 \\
\hline \multicolumn{7}{|l|}{$\mathrm{N}$ content leaves } \\
\hline DC71 & 0.230 & 0.141 & 0.628 & 0.040 & 0.528 & 0.423 \\
\hline DC91 & 0.651 & 0.022 & 0.006 & 0.989 & 0.295 & 0.367 \\
\hline \multicolumn{7}{|l|}{$\mathrm{N}$ content stems } \\
\hline DC71 & 0.267 & 0.164 & 0.230 & 0.325 & 0.538 & 0.512 \\
\hline DC91 & 0.411 & 0.023 & 0.195 & 0.741 & 0.179 & 0.629 \\
\hline
\end{tabular}

${ }^{a}$ DC71 and DC91 phenological stages of durum wheat following the Zadoks Decimal Code. Further explanations are provided in the text. 
Table 3. Cont.

\begin{tabular}{ccccccc}
\hline & ST & Year $\times$ ST & CS & Year $\times$ CS & ST $\times$ CS & Year $\times$ ST $\times$ CS \\
\hline N content ears & & & & & & \\
DC71 & 0.249 & 0.088 & 0.208 & 0.234 & 0.976 & 0.024 \\
DC91 & 0.007 & 0.928 & 0.347 & 0.500 & 0.646 & 0.727 \\
\hline GPC & 0.004 & 0.892 & 0.035 & 0.583 & 0.347 & 0.055 \\
Glia & 0.396 & 0.005 & 0.016 & 0.887 & 0.670 & 0.004 \\
HMW-GS & 0.050 & 0.019 & 0.442 & $<0.001$ & 0.479 & $<0.001$ \\
LMW-GS & 0.083 & 0.004 & 0.590 & $<0.001$ & 0.904 & $<0.001$ \\
GS/GLIA & 0.019 & 0.264 & 0.743 & $<0.001$ & 0.516 & $<0.001$ \\
HMW-G/LMW-GS & 0.402 & 0.002 & 0.204 & 0.650 & 0.251 & 0.014 \\
NDVI & 0.870 & $<0.001$ & 0.982 & 0.158 & 0.937 & 0.231 \\
GNDVI & 0.895 & $<0.001$ & 0.838 & 0.007 & 0.666 & 0.012 \\
OSAVI & 0.969 & $<0.001$ & 0.894 & 0.163 & 0.907 & 0.132 \\
WI & 0.338 & $<0.001$ & 0.678 & 0.156 & 0.301 & 0.008 \\
SPAD & 0.801 & 0.004 & 0.168 & 0.056 & 0.720 & 0.001 \\
\hline
\end{tabular}

${ }^{a}$ DC71 and DC91 phenological stages of durum wheat following the Zadoks Decimal Code. Further explanations are provided in the text.

\subsection{Grain Yield and Yield Components}

The higher grain yields were achieved during 2016 (570 vs. $320 \mathrm{~g} \mathrm{~m}^{-2}$ in 2016 and 2017, respectively) due to the most favorable climatic regime; regardless of the crop growing season, CS induced significant effects, with WF showing higher yields (Tables 3 and 4). In particular, the highest yield was achieved by the combination of $\mathrm{ZT}+\mathrm{WF}$ ( 617 and $370 \mathrm{~g} \mathrm{~m}^{-2}$ in 2016 and 2017, respectively) and the worst by CT + WW (556 and $284 \mathrm{~g} \mathrm{~m}^{-2}$ in 2016 and 2017, respectively). ZT showed a significantly higher number of ears $\mathrm{m}^{-2}$ ( 295 vs. 253 and 304 vs. 267 ears $\mathrm{m}^{-2}$ for ZT and CT in 2016 and 2017, respectively) (Tables 3 and 4).

Table 4. Yield $\left(\mathrm{g} \mathrm{m}^{-2}\right)$, number of ears per square meter (ears, num $\left.\mathrm{m}^{-2}\right)$, and ear length ( $\mathrm{cm}$ ) as recorded at harvest in the 2016 and 2017 cropping seasons. Means followed by different letters (upper case letters: main effects; lower case letters: effects of interaction) significantly differ according to Tukey's HSD test $(p<0.05)$. Treatments: CT, conventional tillage; ZT, zero tillage; WW, durum wheat monocropping; WF, durum wheat-faba bean rotation.

\begin{tabular}{|c|c|c|c|c|c|c|c|c|c|c|}
\hline \multirow{2}{*}{ Year } & \multirow{2}{*}{ Treatments } & \multicolumn{3}{|c|}{ Yield $\left(\mathrm{g} \mathrm{m}^{-2}\right)$} & \multicolumn{3}{|c|}{ Ears (num $\mathrm{m}^{-2}$ ) } & \multicolumn{3}{|c|}{ Ear Length (cm) } \\
\hline & & $\mathrm{ZT}$ & CT & CS Mean & ZT & CT & CS Mean & ZT & CT & CS Mean \\
\hline \multirow[t]{3}{*}{2016} & WW & 551 & 556 & 554 & 273 & 261 & 267 & $7.25 \mathrm{bc}$ & $7.50 \mathrm{~b}$ & 7.37 \\
\hline & WF & 617 & 561 & 589 & 316 & 245 & 281 & $7.28 \mathrm{bc}$ & $8.04 \mathrm{a}$ & 7.66 \\
\hline & ST mean & 584 & 558 & & 295 & 253 & & 7.27 & 7.73 & \\
\hline \multirow[t]{3}{*}{2017} & WW & 319 & 284 & 302 & 296 & 276 & 286 & $6.62 \mathrm{~d}$ & $5.38 \mathrm{f}$ & 6.00 \\
\hline & WF & 370 & 303 & 337 & 312 & 259 & 286 & $7.13 \mathrm{c}$ & $5.73 \mathrm{e}$ & 6.43 \\
\hline & ST mean & 344 & 294 & & 304 & 267 & & 6.88 & 5.56 & \\
\hline \multirow[t]{3}{*}{ 2016-2017 } & WW & 435 & 420 & $428 \mathrm{~B}$ & 285 & 269 & 277 & 6.93 & 6.44 & 6.69 \\
\hline & WF & 494 & 432 & $463 \mathrm{~A}$ & 314 & 252 & 283 & 7.20 & 6.88 & 7.04 \\
\hline & ST mean & 464 & 426 & & $299 \mathrm{~A}$ & $261 \mathrm{~B}$ & & 7.06 & 6.66 & \\
\hline
\end{tabular}

Effects: ST, soil tillage; CS, crop sequence. Degrees of freedom: Year, 1; ST, 1; Year $\times$ ST, 1; CS, 1; Year $\times$ CS, 1 ; $\mathrm{ST} \times \mathrm{CS}, 1$; Year $\times \mathrm{ST} \times \mathrm{CS}, 1$; Residual, 8 .

\subsection{Nitrogen Status, Nitrogen Remobilization Efficiency, and Grain Protein Concentration}

$\mathrm{N}$ concentration in all plant organs (i.e., leaves, stems, and ears) was higher in 2016. Considering the treatments, only the $\mathrm{N}$ concentrations of stems and leaves were significantly influenced by CS and

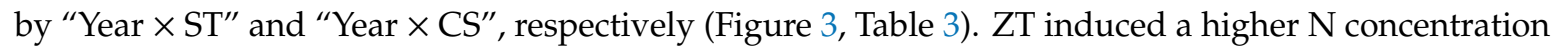
in stems in 2017, while the higher values for stems and leaves in 2016 was observed under WF. 

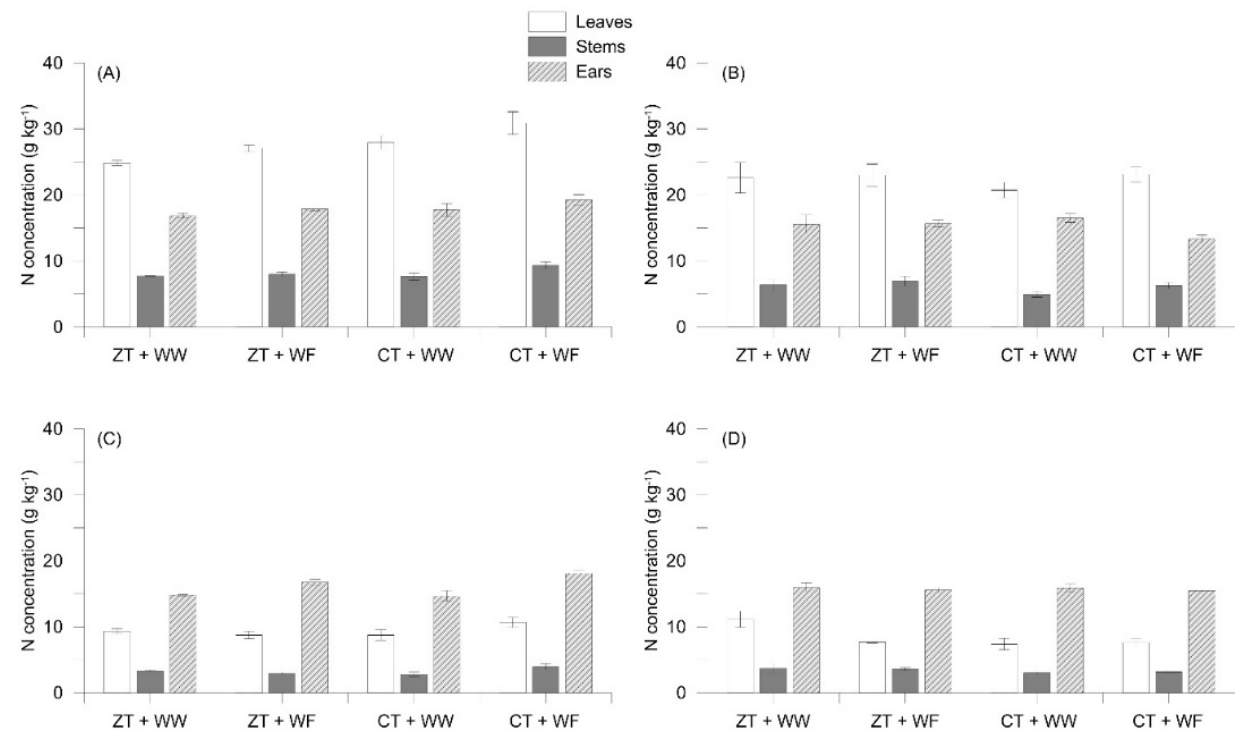

Figure 3. $\mathrm{N}$ concentration $\left(\mathrm{g} \mathrm{kg}^{-1}\right)$ in leaves, stems and ears at DC71 and DC91 phenological stages of durum wheat in 2016 (A and C, respectively) and 2017 (B and D, respectively) cropping seasons. Treatments: CT, conventional tillage; ZT, zero tillage; WW, durum wheat monocropping; WF, durum wheat-faba bean rotation. Data are averages \pm standard errors of $n=3$ independent replicates.

At harvest, differences among the years and treatments reduced drastically. Averaging over treatments, the $\mathrm{N}$ concentration generally decreased in leaves (by $66 \%$ and $62 \%$ in 2016 and 2017, respectively) and stems (by 60\% and 45\% in 2016 and 2017, respectively), while remained substantially unchanged in the ears (17.9 and $16.1 \mathrm{~g} \mathrm{~kg}^{-1}$ in 2016; 15.3 and $15.7 \mathrm{~g} \mathrm{~kg}^{-1}$ in 2017) (Figure 3).

The $\mathrm{N}$ content was confirmed to be higher in 2016 and from post-anthesis to grain filling, it increased significantly in the ears (on average by 3-fold and 2.5-fold increase in 2016 and 2017, respectively) while it reduced in the stems (on average by 75\% and 69\% in 2016 and 2017, respectively) and leaves (on average by $80 \%$ and $84 \%$ in 2016 and 2017, respectively) (Figure 4). ZT always induced significantly higher $\mathrm{N}$ contents (Figure 4, Table 3).
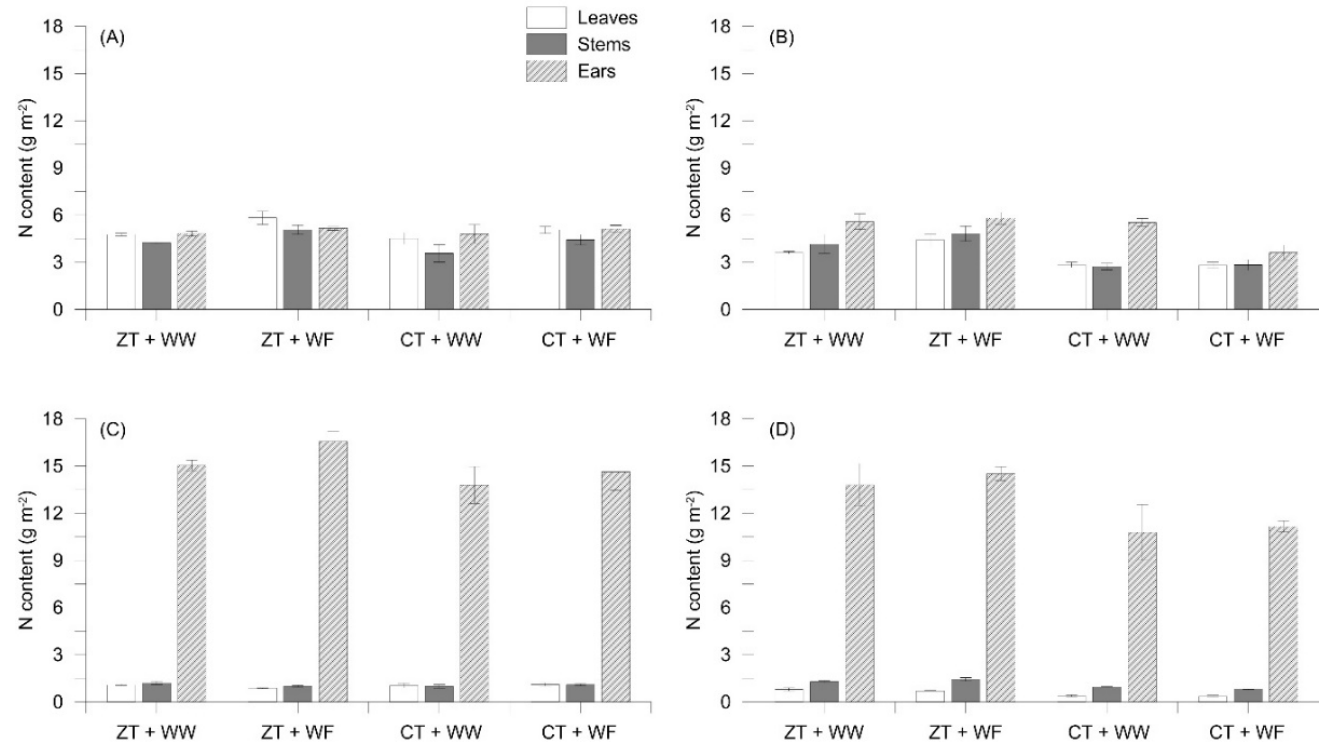

Figure 4. $\mathrm{N}$ content $\left(\mathrm{g} \mathrm{m}^{-2}\right)$ in the leaves, stems, and ears at the DC71 and DC91 phenological stages of durum wheat in 2016 (A and C, respectively) and 2017 (B and D, respectively) cropping seasons. Treatments: CT, conventional tillage; ZT, zero tillage; WW, durum wheat monocropping; WF, durum wheat-faba bean rotation. Data are averages \pm standard errors of $n=3$ independent replicates. 
The amount of $\mathrm{N}$ remobilized into kernels during grain filling were very similar between the years $(77.0 \%$ and $76.0 \%$ in 2016 and 2017, respectively, averaged over ST and CS) (Table 2). The effect of ST was related to the crop growing season (see the significance of the interaction "Year $\times \mathrm{ST}^{\text {" in }}$ Table 3). Furthermore, although not significant, WF induced higher NRemE (79.5\% vs. $74.6 \%$ in 2016 and $77.7 \%$ vs. $74.7 \%$ in 2017 ) (Table 2 ).

The GPC values were similar between the two years (Figure 5), while the effect of both ST and CS was significant $(p<0.05$, Table 3$)$. ZT induced higher values with respect to CT $(12.07 \%$ vs. $10.32 \%)$ and WF than WW (11.52\% vs. $10.87 \%)$; the highest values was obtained by the combination of $\mathrm{ZT}+\mathrm{WF}$ (12.5\%, averaging 2016 and 2017).
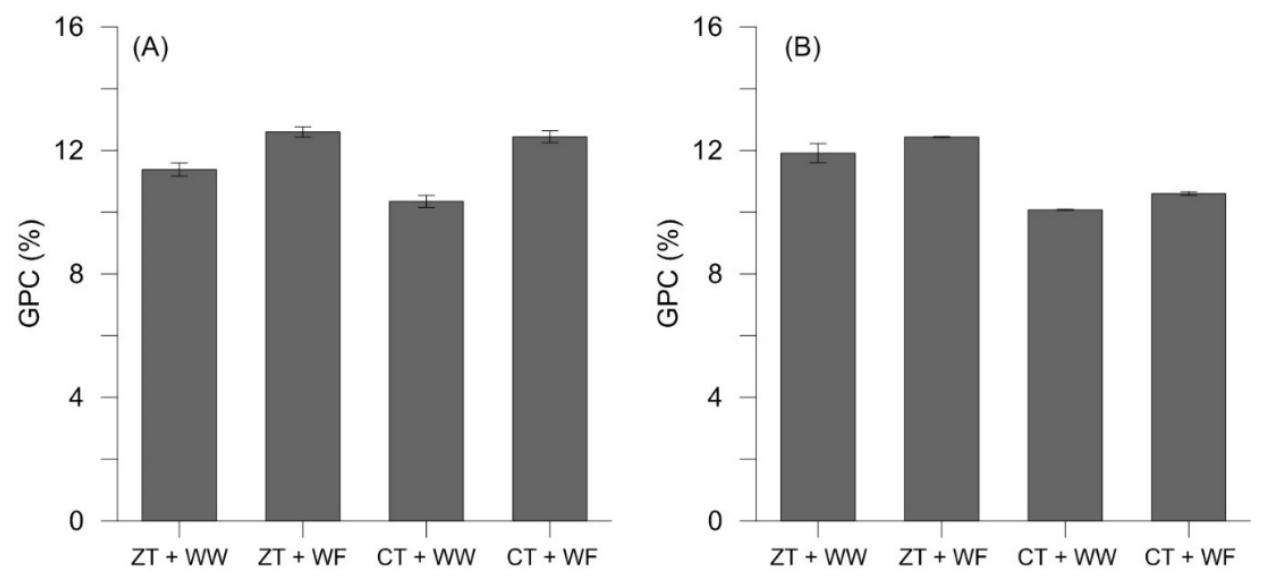

Figure 5. Grain protein content (GPC, \%) as recorded for durum wheat at harvest in the 2016 (A) and 2017 (B) cropping seasons. Treatments: CT, conventional tillage; ZT, zero tillage; WW, durum wheat monocropping; WF, durum wheat-faba bean rotation. Data are averages \pm standard errors of $n=3$ independent replicates.

\subsection{Gluten Proteins Content and Characterization}

The effects of year, ST, and CS on gluten protein characteristics are reported in Table 3. All

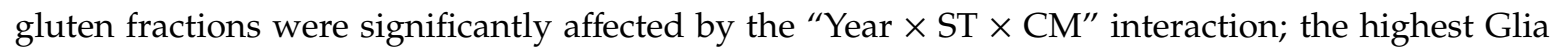
accumulation was obtained by CT + WF in 2017 and the lowest by ZT + WW in 2016 (Table 5). Conversely, the higher kernel accumulation of HMW-GS and LMW-GS were induced by ZT + WF in 2016, while the lowest were generally recorded under CT. A general trend showing higher total GS/Glia and HMW-GS/LMW-GS ratios under ZT with respect to CT was observed (Table 5).

In view of the obtained results, in 2017, the effects of ST and CS were also investigated in terms of the up or downregulation of single sub-units of the Glia, HMW-GS, and LMW-GS (Table 6, Figure 6). With respect to Glia, significant differences were observed in the molecular weight range of $28-41 \mathrm{KDa}$. Despite the interpretation of results being quite challenging, the inclusion of faba bean in the rotation led to $35 \mathrm{KDa}$ and $28 \mathrm{KDa}$ sub-units with a higher relative abundance (highest values reached by CT + WF treatment), while ZT significantly enhanced the $41 \mathrm{kDa}$ subunit (Table 6, Figure 6). Results for the HWM-GS subunits were inconsistent. On the other hand, ZT induced the upregulation of the $42 \mathrm{kDa}$ and $37 \mathrm{kDa}$ (despite not significant) sub-units of LMW-GS (Table 6, Figure 6). Finally, WF significantly induced the downregulation of $42 \mathrm{KDa}, 37 \mathrm{KDa}$, and $40 \mathrm{KDa}$ sub-units of LMW-GS, while significantly enhancing the relative abundance of the $35 \mathrm{KDa}$ sub-unit (+49\% with respect to WW), with the highest values observed in the CT + WF treatment (Table 6, Figure 6). 
Table 5. Gluten fractions (mg g ${ }^{-1}$ flour) (Glia: gliadins; HMW-GS: high molecular weight glutenins; LMW-GS: low molecular weight glutenins; Total GS-: HMW-GS + LMW-GS) and their ratios as recorded at harvest in the 2016 and 2017 cropping seasons. Means followed by different letters (upper case letters: main effects; lower case letters: effects of interaction) significantly differ according to Tukey's HSD test $(p<0.05)$. Treatments: CT, conventional tillage; ZT, zero tillage; WW, durum wheat monocropping; WF, durum wheat-faba bean rotation.

\begin{tabular}{|c|c|c|c|c|c|c|c|c|c|c|c|c|c|c|c|c|}
\hline \multirow{2}{*}{ Year } & \multirow{2}{*}{ Treatments } & \multicolumn{3}{|c|}{ Glia } & \multicolumn{3}{|c|}{ HMW-GS } & \multicolumn{3}{|c|}{ LMW-GS } & \multicolumn{3}{|c|}{ Total GS/GLIA } & \multicolumn{3}{|c|}{ HMW-GS/LMW-GS } \\
\hline & & ZT & CT & CS Mean & ZT & CT & CS Mean & ZT & CT & CS Mean & ZT & CT & CS Mean & $\mathrm{ZT}$ & $\mathrm{CT}$ & CS Mean \\
\hline \multirow[t]{3}{*}{2016} & WW & $9.0 \mathrm{c}$ & $9.4 \mathrm{bc}$ & 9.2 & $1.5 \mathrm{c}$ & $1.3 \mathrm{~d}$ & 1.4 & $2.8 \mathrm{c}$ & $2.0 \mathrm{~d}$ & 2.4 & $0.48 \mathrm{c}$ & $0.35 \mathrm{~d}$ & 0.42 & $0.51 b c$ & $0.62 \mathrm{a}$ & 0.57 \\
\hline & WF & $9.8 \mathrm{bc}$ & $9.8 \mathrm{bc}$ & 9.8 & $2.3 \mathrm{a}$ & $1.1 \mathrm{e}$ & 1.7 & $3.6 \mathrm{a}$ & $2.2 \mathrm{~d}$ & 2.9 & $0.60 \mathrm{a}$ & $0.33 \mathrm{de}$ & 0.47 & $0.65 \mathrm{a}$ & $0.50 \mathrm{c}$ & 0.58 \\
\hline & ST mean & 9.4 & 9.6 & & 1.9 & 1.5 & & 3.2 & 2.1 & & 0.54 & 0.34 & & 0.58 & 0.56 & \\
\hline \multirow[t]{3}{*}{2017} & WW & $9.7 \mathrm{bc}$ & $10.3 \mathrm{~b}$ & 10.0 & $1.9 \mathrm{~b}$ & $1.1 \mathrm{e}$ & 1.5 & $3.2 \mathrm{~b}$ & $2.1 \mathrm{~d}$ & 2.6 & $0.52 \mathrm{~b}$ & $0.31 \mathrm{ef}$ & 0.42 & $0.60 \mathrm{ab}$ & $0.51 b c$ & 0.56 \\
\hline & WF & $9.7 \mathrm{bc}$ & $11.5 \mathrm{a}$ & 10.6 & $1.9 \mathrm{~b}$ & $1.1 \mathrm{e}$ & 1.5 & $2.9 \mathrm{c}$ & $2.3 \mathrm{~d}$ & 2.6 & $0.50 \mathrm{bc}$ & $0.29 \mathrm{f}$ & 0.40 & $0.67 \mathrm{a}$ & $0.48 \mathrm{c}$ & 0.57 \\
\hline & ST mean & 9.7 & 10.9 & & 1.9 & 1.1 & & 3.0 & 2.2 & & 0.51 & 0.30 & & 0.64 & 0.49 & \\
\hline \multirow{3}{*}{ 2016-2017 } & WW & 9.4 & 9.8 & 9.6 & 1.7 & 1.2 & 1.45 & 3.0 & 2.1 & 2.5 & 0.50 & 0.33 & 0.42 & 0.55 & 0.56 & 0.56 \\
\hline & WF & 9.8 & 10.7 & 10.2 & 2.1 & 1.1 & 1.6 & 3.2 & 2.3 & 2.7 & 0.55 & 0.31 & 0.43 & 0.66 & 0.49 & 0.58 \\
\hline & ST mean & 9.6 & 10.3 & & 1.9 & 1.1 & & 3.1 & 2.2 & & 0.53 & 0.32 & & 0.61 & 0.53 & \\
\hline
\end{tabular}

Effects: ST, soil tillage; CS, crop sequence. Degrees of freedom: Year, 1; ST, 1; Year $\times$ ST, 1; CS, 1; Year $\times$ CS, 1; ST $\times$ CS, 1; Year $\times$ ST $\times$ CS, 1; Residual, 8 . 
Table 6. Summary of $p$-values from two-way analysis of variance (ANOVA) on the relative abundances (\%) of Glia, HMW-GS, and LMW-GS detected sub-units in 2017. Effects: ST, soil tillage; CS, crop sequence. Degrees of freedom: ST, 1; CS, 1 ; ST $\times$ CS, 1 ; Residual, 4 .

\begin{tabular}{lccc}
\hline & ST & CS & ST $\times$ CS \\
\hline Glia sub-units & & & \\
$46 \mathrm{KDa}$ & 0.118 & 0.297 & 0.513 \\
$44 \mathrm{KDa}$ & 0.893 & 0.235 & 0.194 \\
$41 \mathrm{KDa}$ & 0.009 & 0.879 & 0.015 \\
$39 \mathrm{KDa}$ & 0.297 & 0.023 & 0.213 \\
$35 \mathrm{KDa}$ & 0.038 & 0.011 & 0.591 \\
$28 \mathrm{KDa}$ & 0.043 & 0.019 & 0.008 \\
\hline HMW-GS sub-units & & & \\
$83 \mathrm{KDa}$ & 0.033 & 0.748 & 0.288 \\
$74 \mathrm{KDa}$ & 0.041 & 0.753 & 0.276 \\
\hline LMW-GS sub-units & & & \\
$42 \mathrm{KDa}$ & 0.023 & 0.027 & 0.067 \\
$41 \mathrm{KDa}$ & 0.421 & 0.759 & 0.860 \\
$40 \mathrm{KDa}$ & 0.125 & 0.036 & 0.089 \\
$37 \mathrm{KDa}$ & 0.050 & 0.002 & 0.142 \\
$35 \mathrm{KDa}$ & 0.058 & $<0.001$ & 0.006 \\
\hline
\end{tabular}
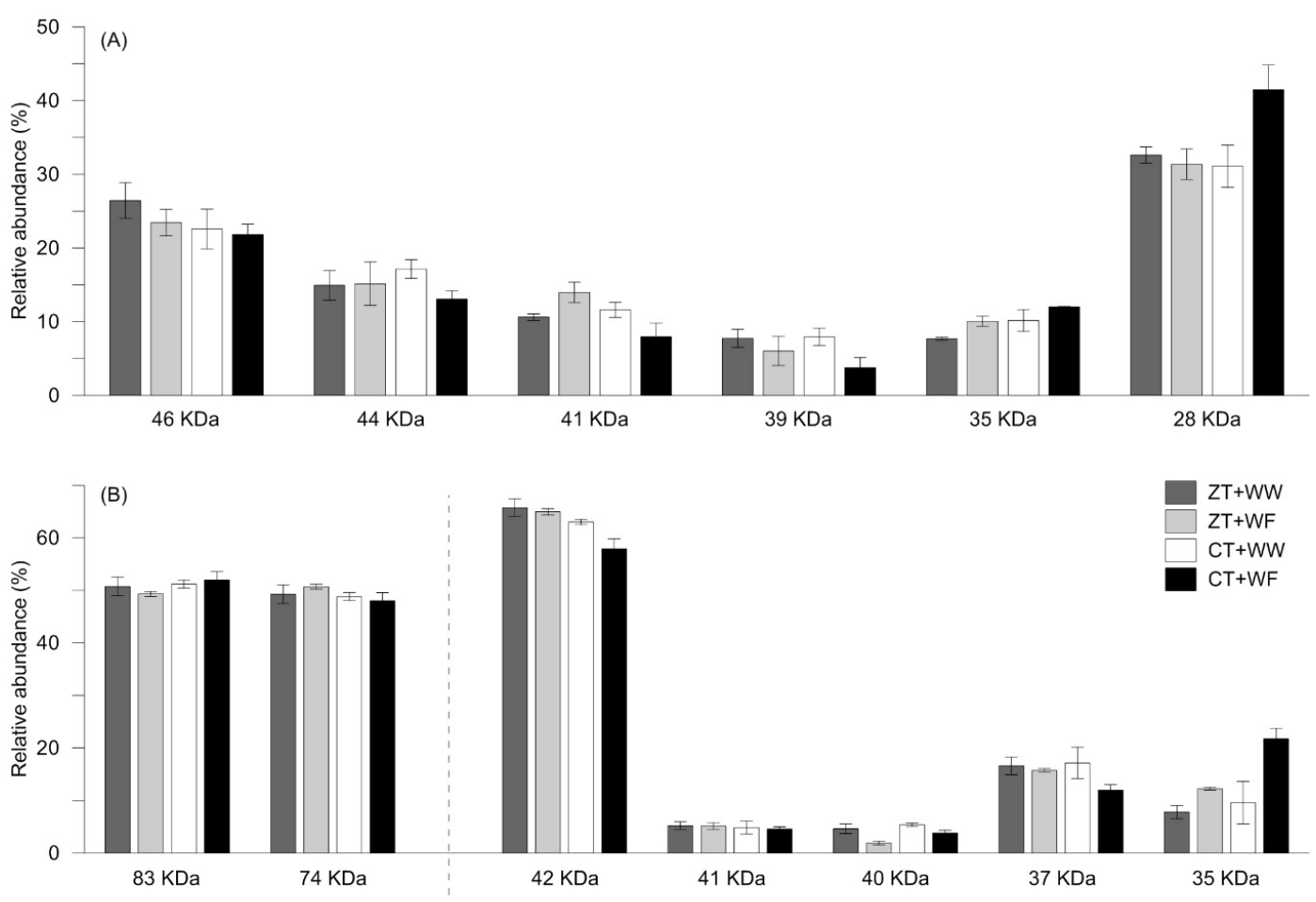

Figure 6. Relative abundances (\%) obtained by the densitometric analysis of Glia (A), HMW-GS, and LMW-GS (B) sub-units of durum wheat in 2017. Treatments: CT, conventional tillage; ZT, zero tillage; WW, durum wheat monocropping; WF, durum wheat-faba bean rotation. Data are averages \pm standard errors of $n=3$ independent replicates.

\subsection{Physiological Traits}

The NDVI, GNDVI, and WI values were significantly higher in 2016. The combinations of $\mathrm{ZT}+\mathrm{WW}$ and $\mathrm{ZT}+\mathrm{WF}$ always registered the highest values and the interaction "Year $\times \mathrm{ST}^{\text {" was }}$ significant $(p<0.05)$ (Tables 3 and 7$)$. 
Table 7. Vegetation indices (NDVI: normalized vegetation index; GNDVI: green normalized difference vegetation index; OSAVI: soil-adjusted vegetation index optimized; WI: Water index) and SPAD values as recorded for durum wheat at the soft dough kernel stage (DC85) in 2016 and 2017 cropping seasons. Means followed by different letters (upper case letters: main effects; lower case letters: effects of interaction) significantly differ according to Tukey's HSD test ( $p<0.05)$. Treatments: $\mathrm{CT}$, conventional tillage; ZT, zero tillage; WW, durum wheat monocropping; WF, durum wheat-faba bean rotation.

\begin{tabular}{|c|c|c|c|c|c|c|c|c|c|c|c|c|c|c|c|c|}
\hline \multirow{2}{*}{ Year } & & \multicolumn{3}{|c|}{ NDVI } & \multicolumn{3}{|c|}{ GNDVI } & \multicolumn{3}{|c|}{ OSAVI } & \multicolumn{3}{|c|}{ WI } & \multicolumn{3}{|c|}{ SPAD } \\
\hline & & ZT & $\mathrm{CT}$ & CS Mean & $\mathrm{ZT}$ & $\mathrm{CT}$ & CS Mean & $\mathrm{ZT}$ & $\mathrm{CT}$ & CS Mean & $\mathrm{ZT}$ & $\mathrm{CT}$ & CS Mean & $\mathrm{ZT}$ & $\mathrm{CT}$ & CS Mean \\
\hline \multicolumn{17}{|l|}{2016} \\
\hline & WW & 0.933 & 0.886 & 0.906 & $0.819 a$ & $0.763 b$ & 0.791 & 0.798 & 0.726 & 0.762 & $1.216 \mathrm{a}$ & $1.032 \mathrm{de}$ & 1.124 & $46.4 \mathrm{~d}$ & $50.1 \mathrm{ab}$ & 48.3 \\
\hline & WF & 0.935 & 0.900 & 0.918 & $0.829 a$ & $0.783 b$ & 0.806 & 0.798 & 0.747 & 0.773 & $1.224 \mathrm{a}$ & $1.074 \mathrm{c}$ & 1.149 & $48.1 \mathrm{c}$ & $50.7 \mathrm{a}$ & 49.4 \\
\hline & ST mean & $0.934 \mathrm{~A}$ & $0.893 \mathrm{~B}$ & & 0.824 & 0.773 & & $0.798 \mathrm{~B}$ & $0.736 \mathrm{C}$ & & 1.220 & 1.053 & & 47.3 & 50.4 & \\
\hline \multicolumn{17}{|l|}{2017} \\
\hline & WW & 0.799 & 0.869 & 0.834 & $0.634 \mathrm{~d}$ & $0.723 c$ & 0.678 & 0.823 & 0.899 & 0.861 & $1.170 \mathrm{~b}$ & $1.051 \mathrm{~cd}$ & 1.105 & $48.4 \mathrm{c}$ & $45.3 \mathrm{~d}$ & 46.85 \\
\hline & WF & 0.799 & 0.854 & 0.826 & $0.642 \mathrm{~d}$ & $0.696 \mathrm{c}$ & 0.669 & 0.824 & 0.883 & 0.854 & $1.157 \mathrm{~b}$ & $1.026 \mathrm{e}$ & 1.091 & $48.9 \mathrm{bc}$ & $48.9 \mathrm{bc}$ & 48.9 \\
\hline & ST mean & $0.799 \mathrm{C}$ & $0.861 \mathrm{~B}$ & & 0.638 & 0.710 & & $0.823 \mathrm{~B}$ & $0.891 \mathrm{~A}$ & & 1.164 & 1.039 & & 48.7 & 48.7 & \\
\hline \multicolumn{17}{|l|}{ 2016-2017 } \\
\hline & WW & 0.866 & 0.877 & 0.871 & 0.726 & 0.743 & 0.734 & 0.810 & 0.813 & 0.812 & 1.124 & 1.111 & 1.175 & 47.4 & 47.7 & 47.55 \\
\hline & WF & 0.867 & 0.877 & 0.872 & 0.736 & 0.740 & 0.738 & 0.811 & 0.815 & 0.813 & 1.149 & 1.091 & 1.120 & 48.5 & 49.8 & 49.2 \\
\hline & ST mean & 0.866 & 0.877 & & 0.736 & 0.741 & & 0.811 & 0.814 & & 1.137 & 1.101 & & 48.0 & 48.7 & \\
\hline
\end{tabular}

Effects: ST, soil tillage; CS, crop sequence. Degrees of freedom: Year, 1; ST, 1; Year $\times$ ST, 1; CS, 1; Year $\times$ CS, 1; ST $\times$ CS, 1; Year $\times$ ST $\times$ CS, 1; Residual, 8 . 
In the case of chlorophyll content in leaves, although the interaction "Year $\times \mathrm{ST} \times \mathrm{CS}$ " was significant, it emerged that WF generally induced higher SPAD values (on average, 49.4 vs. 48.2 for WF and WW, respectively, in 2016 and 48.9 vs. 46.9 for WF and WW, respectively, in 2017).

\section{Discussion}

As it emerges from our work, CA promotes better crop physiological status, which in turns reflects positively on the accumulation of DWs and the quality traits of durum wheat. The determining factor was found in the build-up of a layer of crop residues, which enhance water retention, biological activity, and root development while reducing erosion; the latter acquire a pivotal role under the typical pedo-climatic conditions of Mediterranean environments. In such circumstances, Stagnari et al. [23] showed that $1.5 \mathrm{t} \mathrm{ha}^{-1}$ of straw was enough to produce significantly higher yields, although $2.5 \mathrm{tha}^{-1}$ also guaranteed effects on several crop physiological indicators. The ZT $+\mathrm{WF}$ approach appeared to give better performances, although faba bean accumulated residues were only $0.96 \mathrm{tha}^{-1}$, much lower than the $3.02 \mathrm{t} \mathrm{ha}^{-1}$ obtained under ZT $+\mathrm{WW}$. This can be ascribed to the chemical composition of the residues released. While straw exclusively $(\mathrm{ZT}+\mathrm{WW})$ stimulated $\mathrm{N}$ immobilization (high $\mathrm{C} / \mathrm{N}$ ratio), reducing the immediate availability of $\mathrm{N}$ to the crop [40], the straw/faba bean mixture (ZT + WF) behaved differently, decomposing quicker and supplying a significant amount of $\mathrm{N}$ [41] ad humus. Indeed, the lower $\mathrm{C} / \mathrm{N}$ ratio of the straw/faba bean mixture is known to result in higher humification rates [25,42-44] and easily releases macro and micronutrients [45]. The soil chemical analyses also revealed that, aside from the main effect of soil treatment, the combination of faba bean residues plus straw was more favorable to the build-up of soil organic carbon reserves $(+18 \%$ on average under ZT; data not shown).

Although the observed differences were not significant, higher grain yields values were obtained under ZT, especially under drought conditions and in combination with WF (see higher gaps with CT in 2017) as observed in previous studies correlating yield performances with the crop water stress index [46]. The greater number of ears $\mathrm{m}^{-2}$ was obtained thanks to a higher seed emergence and better crop establishment probably favored by the reduction of water vapor loss from the first layers due to the residue accumulation (ZT) [23,47], although the presence of residues could sometimes promote the movement of phytotoxins toward seedling roots [48]. The CT approach (especially CT + WW) constrained crop growth before anthesis, thus reducing both the size and number of sinks (especially in 2016). Conversely, the higher wheat biomass reached at anthesis under ZT + WF resulted in both a greater accumulation of assimilates available for remobilization and assimilate demand during grain filling [49]. Such pre-anthesis biomass accumulation is critical for maintaining yields when adverse climatic conditions reduce post-anthesis photosynthesis and nutrient uptake [50].

The NDVI, GNDVI, and WI indexes were very successful in detecting plant physiological responses as well as in discriminating among treatments, thus confirming the higher efficiency of the combination of ZT + WF. The WI and NDVI have already been related to water status in plants [51,52] despite being strictly influenced by the relative water content and cell wall elasticity of leaf tissues [53]. Such physiological responses were also remarked by the SPAD readings, which are known to be a good indicator of chlorophyll concentration.

In general, there is a negative relationship between GPC and final grain yield, principally due to the energy constraints and $\mathrm{N}$ dilution effects. However, in accordance with other experimental trials [23,54], the higher protein content in kernels matched the higher yielding combination (ZT + WF), especially in the drought year (see 2017) [55]. The higher soil N availability, obtained with the introduction of a leguminous crop, and the ameliorated soil moisture conditions and nutrient release, due to no mechanical disturbance, most likely improved the wheat $\mathrm{N}$ and water uptake, favoring GPC accumulation [56] and protein quality [57] (i.e., promoting higher gluten fractions and its favorable characteristics [23,58]). During the transition phase to CA it is, indeed, exactly the management of $\mathrm{N}$ fertilization in wheat nutrition, which requires precautions $[59,60]$. We have previously demonstrated that about $150 \mathrm{~kg} \mathrm{~N} \mathrm{ha}^{-1}$, supplied as both calcium nitrate and urea, are required to improve $\mathrm{N}$ uptake 
and metabolic proteins for correct nutrient homeostasis, thus positively impacting on processing wheat quality [18]. In particular, the ratios of GS/Glia and HMW/LMW-GS are positively correlated to dough strength and the addition of a glutenin-rich fraction consisting of HMW-GS to the base semolina increases the mixograph dough strength [61]. The modulation of single protein sub-units of HMW-GS, LMW-GS, $\alpha$-gliadins, $\gamma$-gliadins, and $\omega$-gliadins in response to fertilization management are documented in the literature [62-64], while no information is available on the influence of soil practices and crop rotation on the accumulation of single gluten sub-units. Indeed, gluten protein accumulation is a complex process subjected to spatial and temporal regulation as well as to environmental signaling. Individual proteins within each gluten protein class accumulate to different levels and can be influenced by environmental changes, nutrient availability, and management practices to different extents, suggesting that the corresponding genes have different basal levels of expression and possibly different regulatory elements in the promoter sequences. Our results confirmed the complexity of these processes; however, preliminary conclusions can be drawn. The inclusion of a leguminous crop in the rotation allowed an upregulation of 28-35 KDa sub-units of the Glia fraction, which corresponded to those Glia mainly involved in gluten technological proprieties due to the presence of six $(\alpha / \beta-)$ and eight $(\gamma$-) cysteine residues in the C-terminal domain, with $\gamma$-gliadins forming intra- and inter-chain disulfide bonds interacting with the HMW and LMW polymers [65]. This could be related to the higher $\mathrm{N}$ remobilized to the developing grains. On the other hand, ZT seemed to improve the upregulation of $42 \mathrm{KDa}$ and $37 \mathrm{KDa}$ sub-units of LMWW-GS, which are the most abundant ones, as previously observed in response to the foliar application of $\mathrm{N}$ fertilizers [9]. However, further investigations should be aimed at assessing the effects of CA systems on the expression of gluten protein sub-units.

\section{Conclusions}

Although the transition phases to sustainable agricultural approaches is generally challenging, the application of CA techniques, in particular crop diversification, has allowed for higher durum wheat quality and yield to be achieved. Our work demonstrates that under Mediterranean climates, the application of zero tillage and the introduction of leguminous-based crop rotations exert positive externalities after a six/seven-year period of CA adoption.

The presence of a layer of crop residues and soil organic carbon accumulation is as important as no tillage to improve yield, especially during dry seasons (2017). In addition to a higher yield, ZT and WF practices also ensured higher GPC accumulation in the kernels, probably due to the improved water and nutrient availabilities in line with crop demand during its growth and development.

The ameliorated soil conditions favored the overall crop status, also detected by the reflectance-based indices, as shown with a greater DWRemE and NRemE to the developing grains. Interestingly, the gluten characteristics were also advantaged. Some gluten fractions (i.e., Glia, HMW-GS, and LMW-GS) increased under ZT + WF conditions; ZT seemed to favor the upregulation of the two sub-units of LMW-GS (i.e., $42 \mathrm{KDa}$, the most abundant sub-unit and a marker for wheat quality, and $37 \mathrm{KDa}$ ), while WF positively influenced the upregulation of Glia in the molecular weight range of $28-35 \mathrm{KDa}$ (involved in gluten proprieties).

Under Mediterranean areas, the adoption of CA in durum wheat-based farming systems is a useful choice to combine interesting yield with quality traits (i.e., GPC and LMW-GS) as well as with soil, water, air, and biological benefits.

Author Contributions: Conceptualization, F.S., G.V., and A.G.; Methodology, F.S. and A.G.; Software, S.D. and G.P.; Validation, F.S., G.V., and A.G.; Formal Analysis, S.D. and G.P.; Investigation, G.P. and S.D.; Resources, F.S. and M.P.; Data Curation, F.S., G.V., and A.G.; Writing-Original Draft Preparation, A.G., S.D., F.S., and G.V.; Writing-Review \& Editing, M.P.; Visualization, F.S., G.V., S.D., G.P., and A.G.; Supervision, M.P.

Funding: This research did not receive any specific grants from funding agencies in the public, commercial, or not-for-profit sectors.

Conflicts of Interest: The authors declare no conflicts of interest. 


\section{References}

1. Anderson, W.K.; Impiglia, A. Management of dryland wheat. In Bread Wheat Improvement and Production; Curtis, B.C., Rajaram, S., Gomez Macpherson, H., Eds.; Plant Production and Protection Series, No. 30; FAO: Rome, Italy, 2002; pp. 407-432.

2. Pisante, M.; Stagnari, F.; Acutis, M.; Bindi, M.; Brilli, L.; Di Stefano, V.; Carozzi, M. Conservation agriculture and climate change. In Conservation Agriculture; Farooq, M., Siddique, K., Eds.; Springer International Publishing: Cham, Switzerland, 2015; pp. 579-620.

3. Hobbs, P.R. Conservation agriculture: What is it and why is it important for future sustainable food production? J. Agric. Sci. 2007, 145, 127. [CrossRef]

4. Pisante, M.; Stagnari, F.; Grant, C.A. Agricultural innovations for sustainable crop production intensification. Ital. J. Agron. 2012, 7, 40. [CrossRef]

5. Stagnari, F.; Jan, S.; Angelica, G.; Michele, P. Sustainable agricultural practices for water quality protection. In Water Stress and Crop Plants: A Sustainable Approach; Ahmad, P., Ed.; John Wiley \& Sons: Chichester, UK, 2016; pp. 75-85.

6. Farooq, M.; Flower, K.; Jabran, K.; Wahid, A.; Siddique, K.H. Crop yield and weed management in rainfed conservation agriculture. Soil Tillage Res. 2011, 117, 172-183. [CrossRef]

7. Laino, P.; Shelton, D.; Finnie, C.; De Leonardis, A.M.; Mastrangelo, A.M.; Svensson, B.; Lafiandra, D.; Masci, D. Comparative proteome analysis of metabolic proteins from seeds of durum wheat (cv. Svevo) subjected to heat stress. Proteomics 2010, 10, 2359-2368. [CrossRef] [PubMed]

8. Varzakas, T.; Kozub, N.; Xynias, I.N. Quality determination of wheat: Genetic determination, biochemical markers, seed storage proteins-Bread and durum wheat germplasm. J. Sci. Food Agric. 2014, 94, 2819-2829. [CrossRef] [PubMed]

9. Visioli, G.; Bonas, U.; Dal Cortivo, C.; Pasini, G.; Marmiroli, N.; Mosca, G.; Vamerali, T. Variations in yield and gluten proteins in durum wheat varieties under late-season foliar versus soil application of nitrogen fertilizer in a northern Mediterranean environment. J. Sci. Food Agric. 2018, 98, 2360-2369. [CrossRef] [PubMed]

10. Sissons, J.M. Role of durum wheat composition on the quality of pasta and bread. Food 2008, 2, 75-90.

11. De Vita, P.; Nicosia, O.L.D.; Nigro, F.; Platani, C.; Riefolo, C.; Di Fonzo, N.; Cattivelli, L. Breeding progress in morpho-physiological, agronomical and qualitative traits of durum wheat cultivars released in Italy during the 20th century. Eur. J. Agron. 2007, 26, 39-53. [CrossRef]

12. Dupont, F.; Altenbach, S. Molecular and biochemical impacts of environmental factors on wheat grain development and protein synthesis. J. Cereal Sci. 2003, 38, 133-146. [CrossRef]

13. Graziano, S.; Marando, S.; Prandi, B.; Boukid, F.; Marmiroli, N.; Francia, E.; Pecchioni, N.; Sforza, S.; Visioli, G.; Gullì, M. Technological Quality and Nutritional Value of Two Durum Wheat Varieties Depend on Both Genetic and Environmental Factors. J. Agric. Food Chem. 2019, 67, 2384-2395. [CrossRef]

14. Visioli, G.; Galieni, A.; Stagnari, F.; Bonas, U.; Speca, S.; Faccini, A.; Pisante, M.; Marmiroli, N. Proteomics of Durum Wheat Grain during Transition to Conservation Agriculture. PLoS ONE 2016, 11, e0156007. [CrossRef] [PubMed]

15. López-Bellido, R.; López-Bellido, L. Efficiency of nitrogen in wheat under Mediterranean conditions: Effect of tillage, crop rotation and $\mathrm{N}$ fertilization. Field Crops Res. 2001, 71,31-46. [CrossRef]

16. Dupont, F.M.; Hurkman, W.J.; Vensel, W.H.; Tanaka, C.; Kothari, K.M.; Chung, O.K.; Altenbach, S.B. Protein accumulation and composition in wheat grains: Effects of mineral nutrients and high temperature. Eur. J. Agron. 2006, 25, 96-107. [CrossRef]

17. Kindred, D.R.; Verhoeven, T.M.; Weightman, R.M.; Swanston, J.S.; Agu, R.C.; Brosnan, J.M.; Sylvester-Bradley, R. Effects of variety and fertiliser nitrogen on alcohol yield, grain yield, starch and protein content, and protein composition of winter wheat. J. Cereal Sci. 2008, 48, 46-57. [CrossRef]

18. Galieni, A.; Stagnari, F.; Visioli, G.; Marmiroli, N.; Speca, S.; Angelozzi, G.; D’Egidio, S.; Pisante, M. Nitrogen fertilisation of durum wheat: A case of study in Mediterranean area during transition to conservation agriculture. Ital. J. Agron. 2016, 11, 12-23. [CrossRef]

19. Ranaivoson, L.; Naudin, K.; Ripoche, A.; Affholder, F.; Rabeharisoa, L.; Corbeels, M. Agro-ecological functions of crop residues under conservation agriculture. A review. Agron. Sustain. Dev. 2017, 37, 26. [CrossRef] 
20. Gao, Y.; Li, Y.; Zhang, J.; Liu, W.; Dang, Z.; Cao, W.; Qiang, Q. Effects of mulch, N fertilizer, and plant density on wheat yield, wheat nitrogen uptake, and residual soil nitrate in a dryland area of China. Nutr. Cycl. Agroecosyst. 2009, 85, 109-121. [CrossRef]

21. Baker, J.M.; Ochsner, T.E.; Venterea, R.T.; Griffis, T.J. Tillage and soil carbon sequestration-What do we really know? Agric. Ecosyst. Environ. 2007, 118, 1-5. [CrossRef]

22. Nishigaki, T.; Sugihara, S.; Kilasara, M.; Funakawa, S. Soil nitrogen dynamics under different quality and application methods of crop residues in maize croplands with contrasting soil textures in Tanzania. Soil Sci. Plant Nutr. 2017, 63, 288-299. [CrossRef]

23. Stagnari, F.; Galieni, A.; Speca, S.; Cafiero, G.; Pisante, M. Effects of straw mulch on growth and yield of durum wheat during transition to Conservation Agriculture in Mediterranean environment. Field Crops Res. 2014, 167, 51-63. [CrossRef]

24. Cherr, C.M.; Scholberg, J.M.S.; McSorley, R. Green Manure as Nitrogen Source for Sweet Corn in a Warm-Temperate Environment. Agron. J. 2006, 98, 1173-1180. [CrossRef]

25. Stagnari, F.; Pisante, M. Managing faba bean residues to enhance the fruit quality of the melon (Cucumis melo L.) crop. Sci. Hortic. 2010, 126, 317-323. [CrossRef]

26. Knowler, D.; Bradshaw, B. Farmers' adoption of conservation agriculture: A review and synthesis of recent research. Food Policy 2007, 32, 25-48. [CrossRef]

27. Campiglia, E.; Mancinelli, R.; De Stefanis, E.; Pucciarmati, S.; Radicetti, E. The long-term effects of conventional and organic cropping systems, tillage managements and weather conditions on yield and grain quality of durum wheat (Triticum durum Desf.) in the Mediterranean environment of Central Italy. Field Crops Res. 2015, 176, 34-44. [CrossRef]

28. Govaerts, B.; Sayre, K.D.; Deckers, J. Stable high yields with zero tillage and permanent bed planting? Field Crops Res. 2005, 94, 33-42. [CrossRef]

29. Ververis, C.; Georghiou, K.; Danielidis, D.; Hatzinikolaou, D.; Santas, P.; Santas, R.; Corleti, V. Cellulose, hemicelluloses, lignin and ash content of some organic materials and their suitability for use as paper pulp supplements. Bioresour. Technol. 2007, 98, 296-301. [CrossRef]

30. Zadoks, J.C.; Chang, T.T.; Konzak, C.F. A decimal code for the growth stages of cereals. Weed Res. 1974, 14, 415-421. [CrossRef]

31. Arduini, I.; Masoni, A.; Ercoli, L.; Mariotti, M. Grain yield, and dry matter and nitrogen accumulation and remobilization in durum wheat as affected by variety and seeding rate. Eur. J. Agron. 2006, 25, 309-318. [CrossRef]

32. Sosulski, F.W.; Imafidon, G.I. Amino acid composition and nitrogen-to-protein conversion factors for animal and plant foods. J. Agric. Food Chem. 1990, 38, 1351-1356. [CrossRef]

33. Singh, V.; Moreau, R.A.; Doner, L.W.; Eckhoff, S.R.; Hicks, K.B. Recovery of Fiber in the Corn Dry-Grind Ethanol Process: A Feedstock for Valuable Coproducts. Cereal Chem. J. 1999, 76, 868-872. [CrossRef]

34. Rouse, J.W.; Haas, R.H.; Schell, J.A.; Deering, D.W. Monitoring vegetation systems in the Great Plains with ERTS. In Proceedings of the Third ERTS Symposium, NASA SP-351, Washington, DC, USA, 10-14 December 1973; pp. 309-317.

35. Gitelson, A.A.; Merzlyak, M.N. Signature Analysis of Leaf Reflectance Spectra: Algorithm Development for Remote Sensing of Chlorophyll. J. Plant Physiol. 1996, 148, 494-500. [CrossRef]

36. Peñuelas, J.; Pinol, J.; Ogaya, R.; Filella, I. Estimation of plant water concentration by the reflectance Water Index WI (R900/R970). Int. J. Remote Sens. 1997, 18, 2869-2875. [CrossRef]

37. Rondeaux, G.; Steven, M.; Baret, F. Optimization of soil-adjusted vegetation indices. Remote Sens. Environ. 1996, 55, 95-107. [CrossRef]

38. Onofri, A. Routine statistical analyses of field experiments by using an Excel extension. In Proceedings of the 6th National Conference Italian Biometric Society: "La Statistica Nelle Scienze Della Vita e Dell'ambiente", Pisa, Italy, 20-22 June 2007; pp. 93-99.

39. R Core Team. R: A Language and Environment for Statistical Computing; R Foundation for Statistical Computing: Vienna, Austria, 2017.

40. Scott, B.J.; Eberbach, P.L.; Evans, J.; Wade, L.J. Stubble Retention in Cropping Systems in Southern Australia: Benefits and Challenges; EH Graham Centre Monograph No. 1; Industry and Investment NSW: Wagga, Australia, 2010. 
41. Van Kessel, C.; Hartley, C. Agricultural management of grain legumes: Has it led to an increase in nitrogen fixation? Field Crops Res. 2000, 65, 165-181. [CrossRef]

42. Trinsoutrot, I.; Recous, S.; Bentz, B.; Lineres, M.; Cheres, M.; Cheneby, D.; Nicolardot, B. Biochemical Quality of Crop Residues and Carbon and Nitrogen Mineralization Kinetics under Nonlimiting Nitrogen Conditions. Soil Sci. Soc. Am. J. 2000, 64, 918-926. [CrossRef]

43. Hadas, A.; Kautsky, L.; Goek, M.; Kara, E.E. Rates of decomposition of plant residues and available nitrogen in soil, related to residue composition through simulation of carbon and nitrogen turnover. Soil Biol. Biochem. 2004, 36, 255-266. [CrossRef]

44. Galieni, A.; Stagnari, F.; Speca, S.; D’Egidio, S.; Pagnani, G.; Pisante, M. Management of crop residues to improve quality traits of tomato (Solanum lycopersicum L.) fruits. Ital. J. Agron. 2017, 12. [CrossRef]

45. Lupwayi, N.Z.; Clayton, G.W.; Lea, T.; Beaudoin, J.L. Soil microbial biomass, functional diversity and crop yields following application of cattle manure, hog manure and inorganic fertilizers. Can. J. Soil Sci. 2005, 85, 193-201. [CrossRef]

46. Amato, G.; Ruisi, P.; Frenda, A.S.; Di Miceli, G.; Saia, S.; Plaia, A.; Giambalvo, D. Long-Term Tillage and Crop Sequence Effects on Wheat Grain Yield and Quality. Agron. J. 2013, 105, 1317-1327. [CrossRef]

47. Wuest, S.B.; Albrecht, S.L.; Skirvin, K.W. Crop residue position and interference with wheat seedling development. Soil Tillage Res. 2000, 55, 175-182. [CrossRef]

48. Rebetzke, G.J.; Bruce, S.E.; Kirkegaard, J.A. Longer coleoptiles improve emergence through crop residues to increase seedling number and biomass in wheat (Triticum aestivum L.). Plant Soil 2005, 272, 87-100. [CrossRef]

49. Masoni, A.; Ercoli, L.; Mariotti, M.; Arduini, I. Post-anthesis accumulation and remobilization of dry matter, nitrogen and phosphorus in durum wheat as affected by soil type. Eur. J. Agron. 2007, 26, 179-186. [CrossRef]

50. Tahir, I.S.A.; Nakata, N. Remobilization of Nitrogen and Carbohydrate from Stems of Bread Wheat in Response to Heat Stress during Grain Filling. J. Agron. Crop Sci. 2005, 191, 106-115. [CrossRef]

51. Zhang, J.; Shi, L.; Shi, A.; Zhang, Q. Photosynthetic Responses of Four Hosta Cultivars to Shade Treatments. Photosynthetica 2004, 42, 213-218. [CrossRef]

52. Zhang, J.; Xu, Y.; Yao, F.; Wang, P.; Guo, W.; Li, L.; Yang, L. Advances in estimation methods of vegetation water content based on optical remote sensing techniques. Sci. China Ser. E Technol. Sci. 2010, 53, 1159-1167. [CrossRef]

53. Peñuelas, J.; Filella, I.; Biel, C.; Serrano, L.; Savé, R. The reflectance at the 950-970 nm region as an indicator of plant water status. Int. J. Remote Sens. 1993, 14, 1887-1905. [CrossRef]

54. Lovera, K.R.; Davies, W.P.; Cannon, N.D.; Conway, J.S. Influence of tillage systems and nitrogen management on grain yield, grain protein and nitrogen-use efficiency in UK spring wheat. J. Agric. Sci. 2016, 154,1437-1452. [CrossRef]

55. Stagnari, F.; Galieni, A.; Pisante, M. Drought stress effects on crop quality. In Water Stress and Crop Plants: A Sustainable Approach; Parvaiz, A., Ed.; John Wiley \& Sons, Ltd.: Amsterdam, The Netherlands, 2016; pp. 375-392.

56. Gao, X.; Lukow, O.M.; Grant, C.A. Grain concentrations of protein, iron and zinc and bread making quality in spring wheat as affected by seeding date and nitrogen fertilizer management. J. Geochem. Explor. 2012, 121, 36-44. [CrossRef]

57. Zhang, P.; Ma, G.; Wang, C.; Lu, H.; Li, S.; Xie, Y.; Zhu, Y.; Guo, T. Effect of irrigation and nitrogen application on grain amino acid composition and protein quality in winter wheat. PLoS ONE 2017, 12, e0178494. [CrossRef]

58. Mrabet, R.; Ibno-Namr, K.; Bessam, F.; Saber, N.; Ibno-Namr, K. Soil chemical quality changes and implications for fertilizer management after 11 years of no-tillage wheat production systems in semiarid Morocco. Land Degrad. Dev. 2001, 12, 505-517. [CrossRef]

59. Pellegrino, E.; Bosco, S.; Ciccolini, V.; Pistocchi, C.; Sabbatini, T.; Silvestri, N.; Bonari, E. Agricultural abandonment in Mediterranean reclaimed peaty soils: Long-term effects on soil chemical properties, arbuscular mycorrhizas and $\mathrm{CO}_{2}$ flux. Agric. Ecosyst. Environ. 2015, 199, 164-175. [CrossRef]

60. Ciccolini, V.; Bonari, E.; Ercoli, L.; Pellegrino, E. Phylogenetic and multivariate analyses to determine the effect of agricultural land-use intensification and soil physico-chemical properties on N-cycling microbial communities in drained Mediterranean peaty soils. Biol. Fertil. Soils 2016, 52, 811-824. [CrossRef]

61. Edwards, N.M.; Mulvaney, S.J.; Scanlon, M.G.; Dexter, J.E. Role of gluten and its components in determining durum semolina dough viscoelastic proprieties. Cereal Chem. 2003, 80, 755-763. [CrossRef] 
62. Hurkman, W.J.; Tanaka, C.K.; Vensel, W.H.; Thilmony, R.; Altenbach, S.B. Comparative proteomic analysis of the effect of temperature and fertiliser on gliadin and glutenin accumulation in the developing endosperm and flour from Triticum aestivum L. cv. Butte 86. Proteome Sci. 2013, 11, 8. [CrossRef] [PubMed]

63. Wan, Y.; Shewry, R.P.; Hawkesford, J. A novel family of $\gamma$-gliadin genes are highly regulated by nitrogen supply in developing wheat grain. J. Exp. Bot. 2013, 64, 161-168. [CrossRef] [PubMed]

64. Visioli, G.; Comastri, A.; Imperiale, D.; Paredi, G.; Faccini, A.; Marmiroli, N. Gel-based and gel-free analytical methods for the analysis of HMW-GS and LMW-GS in wheat flour. Food Anal. Methods 2016, 9, 469-474. [CrossRef]

65. Wieser, H. Chemistry of gluten proteins. Food Microbiol. 2007, 24, 115-119. [CrossRef] [PubMed]

(C) 2019 by the authors. Licensee MDPI, Basel, Switzerland. This article is an open access article distributed under the terms and conditions of the Creative Commons Attribution (CC BY) license (http://creativecommons.org/licenses/by/4.0/). 